International Journal of Advanced Trends in Computer Science and Engineering

Available Online at http://www.warse.org/IJATCSE/static/pdf/file/ijatcse0481.12019.pdf

https://doi.org/10.30534/ijatcse/2019/0481.12019

\title{
Life Cycle Assessment Use For Identification Of Environmental Profiles Of Different Scenarios For Handling Defective Products
}

\author{
Tomasz Nitkiewicz ${ }^{1}$, Katarzyna Grondys ${ }^{2}$ \\ Centre of Life Cycle Modeling, Faculty of Management, Czestochowa University of Technology Czestochowa, \\ Al. Armii Krajowej 19B, 42-200 Częstochowa, Poland \\ tomaszn@zim.pcz.pl \\ ${ }^{2}$ katarzyna_grondys@vp.pl
}

\begin{abstract}
The aim of the article is to assess environmental loads credited to handling defective products. The assessment is made on the case of manufacturer of driveline products for automobiles. Life cycle assessment is used for that purpose. According to the company procedures of handling defective products several scenarios are build. For each scenario processes with possible environmental impacts are identified. In the final step, the impacts are calculated with life cycle assessment method.
\end{abstract}

Keywords: life cycle assessment, defective products handling, end-of-life scenarios, automotive sector

\section{INTRODUCTION}

Environmental performance seem to be one of the criterion that constitutes companies competitive advantage and market approach. It is visible in the area of environmental technology sectors, but also become more and more important competitive factor in other sectors. These would certainly include automotive sector with its highly resource consuming industry, both in manufacturing and in usage phases of product life cycle. Our study refers to very specific aspect of car manufacturing process, namely, to the defects handling scenarios considered from the perspective of environmental impacts. For that purpose we use the example of driveline products manufacturer and adapt life cycle assessment method to measure environmental consequences of different scenarios for handling defective products.

The process of handling defective and returned products are investigated from the perspective of logistics management by some authors and research groups. Logistics management in the primal scope of its interests has been created for traditional

- forward - product flow [7]. But together with changes in business practice, regulator efforts and customer expectations, the scope of logistic management start to include also not forward flows of functional products but also backward flows of defective, returned products, materials or wastes [11]. Logistics management of defective products (returns) in brief refers to managing products that flow backwards in the supply chain, causing the need to handle reverse movement of materials in the supply chain [5]. Slowly, process of handling defective process has become a part of production logistics and has more and more implication for inventory management and production planning [2]. Starostka-Patyk, who makes an effort

The paper is based on the research results within project „Logistic management of defective products" with financing by Polish National Centre of Science with decision number DEC-2012/07/D/HS4/02071. to address the defective product management issue from the perspective of whole economy, finds that returns acceptance policy in companies is highly driven by both institutional and customer related pressures [10].

Our approach, namely, assessment of environmental impact of different approaches to handle defective product management has been also present in the literature. Pallaro et al., who made the review of sustainable production and consumption literature that addresses the automotive sector, indicate repair, reuse and remanufacturing efforts as building blocks for end-of-life treatment [8]. Since the issue of defected product handling is similar to waste management in a sense of different scenarios it is worth to bring out also some approaches to management of specific waste types. Guarnieri et al. use Strategic Options Development Analysis methodology to build up actors' map and decision trees for reverse logistics of e-waste [3]. In the same sector, Prakash and Barua, use Fuzzy AHP approach for the selection of thirdparty logistics partner for handling e-waste [9]. Agrewal et al. use different measures, including environmental impact, to assess and support, what they call, disposition decisions [1]. Similar to ours approach with LCA is used by Starostka-Patyk and Nitkiewicz with reference to mobile phones [6]. Interesting study, with orientation on spare part management is made by Grondys, but environmental impacts are not directly addressed [4].

\section{COMPANY AND ITS PROCEDURE OF HANDLING DEFECTS}

\subsection{Profile of the Company}

The company under investigation wished to stay anonymous and is referred simply as "company" in the paper. The company is a multinational manufacturer of number of driveline products and related spare parts for automobiles with several business units all over. In supply chain it realizes functions of designer, manufacturer and retailer of its products. The circle of its customer includes producers and users of light and heavy vehicles, agriculture use vehicles, construction and industry vehicles. All its products are produced with materials and components from selected group of long-term suppliers that have introduced required elements of quality system. The group of customers includes well known car producers such as Volvo, Ford, Fiat, Mercedes and many others. 
The production profile of the company includes such products as dirveshafts, sideshafts, differentials and aluminum die castings. The study refers to one of its business units that operates seven production and assembly lines.

\subsection{Specifications of driveshaft manufacturing line}

One of them is driveshaft production / assembly line. The driveshaft is assembled from the shaft, front yoke, rear flange and two u-joints with seals. The shaft, front yoke and flange are produced on-site while u-joints and their seals are manufactured and delivered by the suppliers. Assembled driveshaft is delivered to the car manufacturer. Basic parameter of driveshaft manufacturing line are presented in Tab. I.

Table 1: . BASIC PARAMETERS OF COMPANY DRIVESHAFT MANUFACTURING LINE

\begin{tabular}{|c|r|}
\hline Parameter & \multicolumn{1}{|c|}{ Value } \\
\hline Driveshaft weight [kg] & 8,58 \\
\hline Driveshaft length [m] & 1,25 \\
\hline $\begin{array}{c}\text { Manufacturing batch in a cycle } \\
\text { [no. of pieces] }\end{array}$ & 31000 \\
\hline $\begin{array}{c}\text { Yearly production volume } \\
\text { [no. of pieces] }\end{array}$ & 620000 \\
\hline Contract longitude [no. of years] & 950 \\
\hline Distance to the customer assembly line [km] & 250 \\
\hline Distance to the supplier [km] & \\
\hline
\end{tabular}

\subsection{Procedure of handling defective products}

According to the procedure of handling defects in manufacturing process some scenarios could be distinguished. In Tab. II the basic features of selected scenarios are presented. In fact the number of possible scenarios is much higher but for the sake of clarity only these four are studied. Other scenarios are not considered but it is worth to mention the criteria that would evoke them. One of this criterion could be the moment of identifying the defect. In all of the scenarios presented below the defect if identified in the manufacturing process. Alternatively, it could be identified by the customer, and then, each of the scenarios would have additional step, namely, transport to the customer and back. None of the scenarios considered refers to products or its components that would be classified as defected and not possible to be recovered. It is not often the case in investigated company but could happen and would change the environmental outcomes in a significant manner. Since, it is not popular case it is not considered.

\subsection{Environmental impacts in defective products handling}

For all the scenarios it is assumed that $10 \%$ of batch (or component batch) are identified as defected. It is again simplifying assumption, that would made study more prone to interpretation while environmental impacts are concerned. Tab.

III presents the possible environmental impacts in selected scenarios. In general, these impacts are related to transports and remanufacturing and repairing processes. Some activities, that could also contribute to environmental impacts but in a not significant manner are omitted in the study. All the impacts related to given scenario are denoted with 1 .
Table 2:

CHARACTERISTICS OF SELECTED SCENARIOS FOR HANDLING DEFECTIVE PRODUCTS

\begin{tabular}{|c|c|}
\hline Number & Content \\
\hline $\begin{array}{c}\text { Scenario } \\
1\end{array}$ & $\begin{array}{l}\text { The quality assessment control identifies the } \\
\text { product as non-compliant with quality criteria. } \\
\text { It is furtherly assessed and classified as whole } \\
\text { product defect. In further procedure whole } \\
\text { manufacturing batch is stopped for control. The } \\
\text { assessment classifies } 10 \% \text { of a batch as defected } \\
\text { while remaining part is coming back to the } \\
\text { manufacturing process. Defected products are } \\
\text { identified as repairable and treated according to } \\
\text { their defect and are coming back to the } \\
\text { manufacturing process. }\end{array}$ \\
\hline $\begin{array}{c}\text { Scenario } \\
2\end{array}$ & $\begin{array}{l}\text { The quality assessment control identifies the } \\
\text { product as non-compliant with quality criteria. } \\
\text { It is furtherly assessed and classified as product } \\
\text { component defect. In further procedure whole } \\
\text { component batch is stopped for control. The } \\
\text { assessment classifies } 10 \% \text { of a component batch } \\
\text { as defected while remaining part is coming back } \\
\text { to the manufacturing process. Defected } \\
\text { components are identified as repairable and } \\
\text { treated according to their defect and are coming } \\
\text { back to the manufacturing process. }\end{array}$ \\
\hline $\begin{array}{c}\text { Scenario } \\
3\end{array}$ & $\begin{array}{l}\text { During the manufacturing process the quality } \\
\text { assessment control identifies the product as } \\
\text { non-compliant with quality criteria. It is } \\
\text { furtherly assessed and classified as product } \\
\text { component defect. In further procedure whole } \\
\text { component batch is stopped for control and the } \\
\text { defect is assigned to the supplier that is notified. } \\
\text { The assessment classifies } 10 \% \text { of a component } \\
\text { batch as defected while remaining part is } \\
\text { coming back to the manufacturing process. } \\
\text { Defected components are identified as } \\
\text { repairable, and since they are needed in the } \\
\text { manufacturing process, they are treated on site } \\
\text { according to their defect and are coming back to } \\
\text { the manufacturing. }\end{array}$ \\
\hline $\begin{array}{c}\text { Scenario } \\
4\end{array}$ & $\begin{array}{l}\text { During the manufacturing process the quality } \\
\text { assessment control identifies the product as } \\
\text { non-compliant with quality criteria. It is } \\
\text { furtherly assessed and classified as product } \\
\text { component defect. In further procedure whole } \\
\text { component batch is stopped for control and the } \\
\text { defect is assigned to the supplier that is notified. } \\
\text { The assessment classifies } 10 \% \text { of a component } \\
\text { batch as defected while remaining part is } \\
\text { coming back to the manufacturing process. } \\
\text { Since defected components are not needed in } \\
\text { the manufacturing process, they are send back } \\
\text { to the supplier. }\end{array}$ \\
\hline
\end{tabular}


Table 3: $\quad$ PRocessing OF SELECTED SCENARIOS WITH POTENTIAL OF EVOKING ENVIRONMENTAL IMPACTS

\begin{tabular}{|l|l|l|l|l|}
\hline Environmental impacts & S1 & S2 & S3 & S4 \\
\hline Internal transport of product batch & 1 & 0 & 0 & 0 \\
\hline Remanufacturing & 1 & 1 & 1 & 1 \\
\hline Repair (mechanical machining) & 1 & 1 & 1 & 0 \\
\hline Internal transport of component batch & 0 & 0 & 1 & 1 \\
\hline External transport to supplier & 0 & 0 & 0 & 1 \\
\hline
\end{tabular}

\section{LIFE CYCLE ASSESSMENT OF DEFECTIVE PRODUCTS} HANDLING SCENARIOS

\subsection{Scope of the study and life cycle inventory}

A functional unit for the assessment is "gate to gate" scenario for 1 driveshaft with some defects identified in the manufacturing process. The defects and their handling are different for each one of the scenarios considered. Tab. IV presents life cycle inventory for materials used in assembling driveshaft. Materials are grouped into several categories only and reflect their content in final product. With ecoinvent 3.1 database the material flows are subscribed with environmental impacts. For the impact assessment phase of LCA ReCiPe endpoint method is used with reference to Europe and hierarchist perspective assumptions.

Table 4: LIFE CYCLE INVENTORY FOR MATERIALS USED IN FUNCTIONAL UNIT

\begin{tabular}{|l|r|r|}
\hline \multicolumn{1}{|c|}{ materials } & \multicolumn{1}{c|}{$\begin{array}{c}\text { weight } \\
{[\mathbf{k g}]}\end{array}$} & $\begin{array}{c}\text { overall share } \\
{[\%]}\end{array}$ \\
\hline steel & 6,72 & $78,3 \%$ \\
\hline chromium steel & 1,43 & $16,7 \%$ \\
\hline rubber & 0,17 & $2,0 \%$ \\
\hline silicone & 0,09 & $1,0 \%$ \\
\hline neoprene & 0,09 & $1,0 \%$ \\
\hline $\begin{array}{l}\text { high temperature thermoplasts } \\
\text { (nylon) }\end{array}$ & 0,09 & $1,0 \%$ \\
\hline total & 8,58 & $100,0 \%$ \\
\hline
\end{tabular}

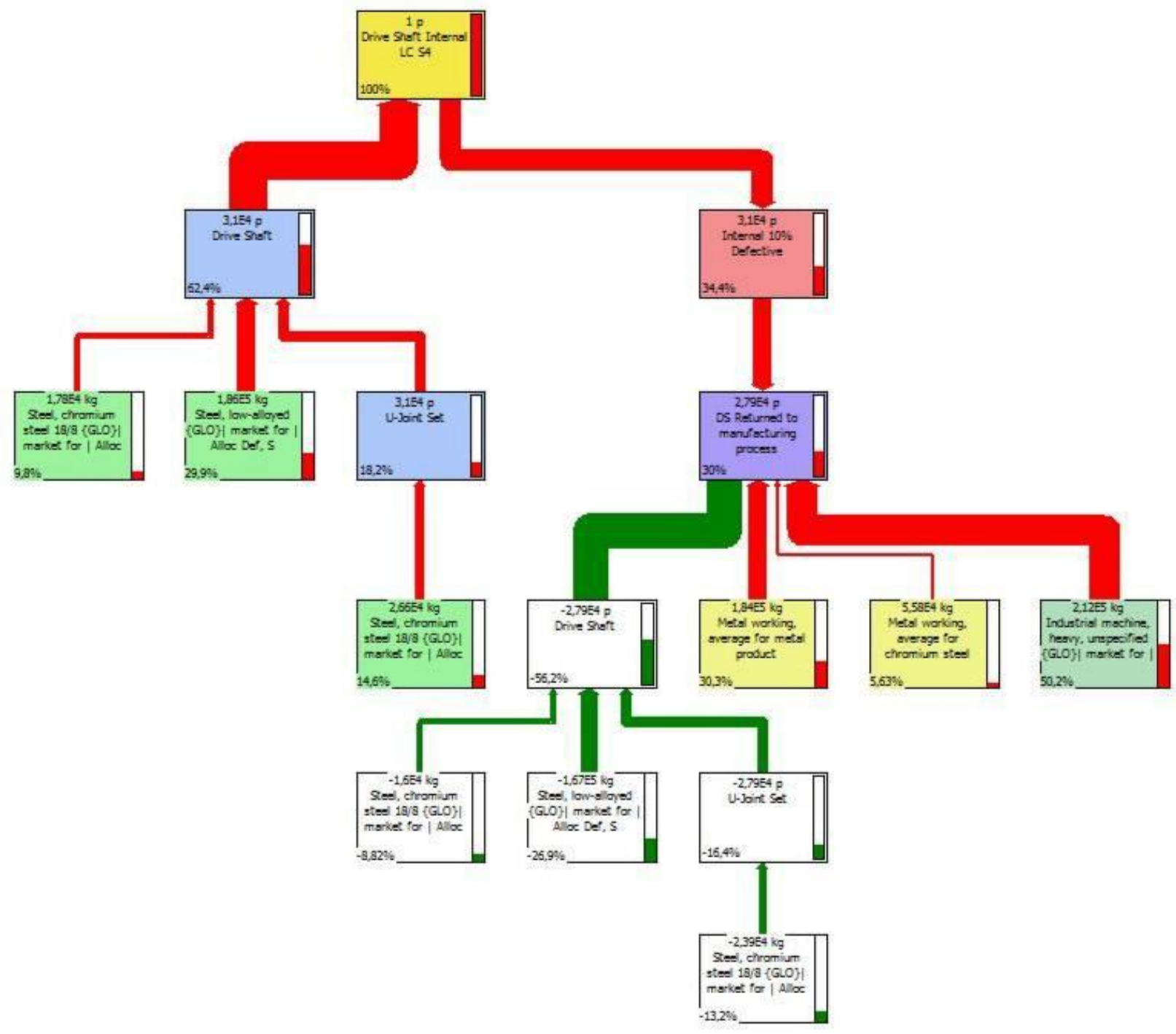

Figure 1.: Flow diagram for Scenario 4 - contribution of processes to ReCiPe single score indicator 




Figure 2: . Comparison of ReCiPe weighted damage category indicators for selected scenarios

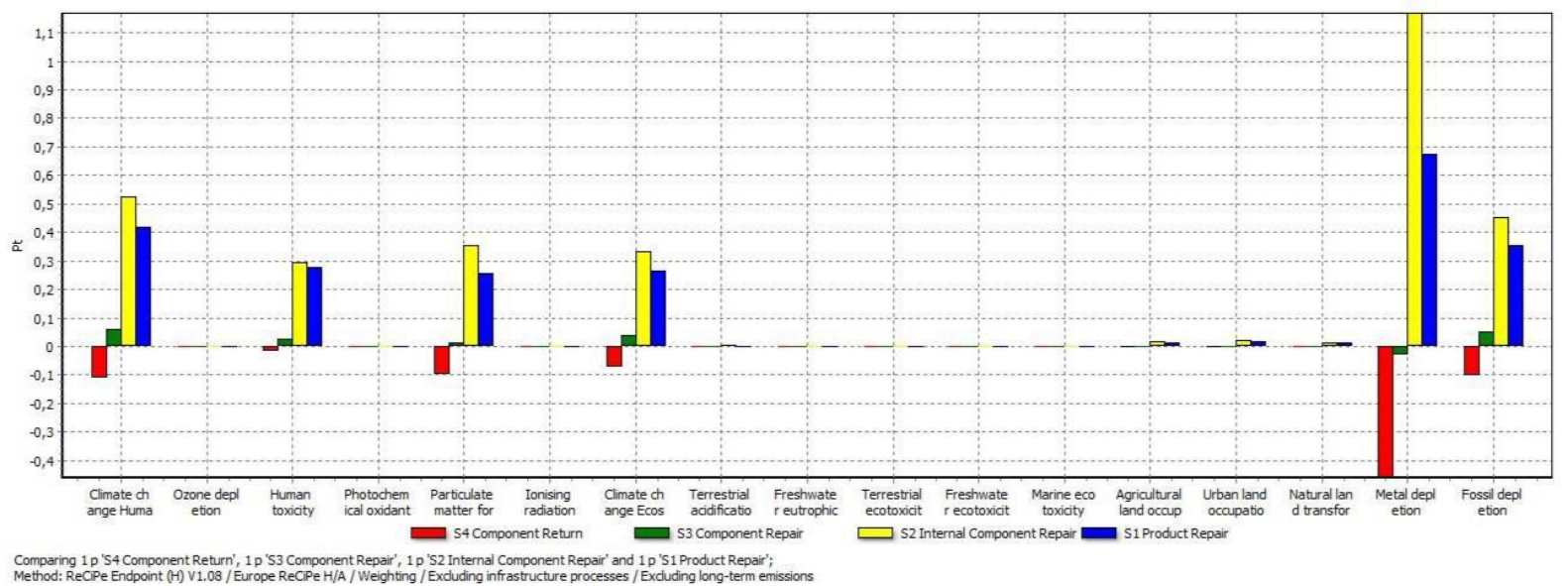

Figure 3:. Comparison of ReCiPe weighted impact category indicators for selected scenarios

\subsection{Life cycle impact assessment}

Figure 1 presents the flow of overall impact for Scenario 4 as measured by ReCiPe single score indicator. The thickness of lines represents the share of given material in overall impact. The red color lines refer to processes that negatively contribute to overall impact, while green color lines represent the positive impact. In our case positive impact is related to returning materials to manufacturing process after they are identified as not defected. Negative impacts are related to manufacturing, remanufacturing and repair processes and to materials use during the processing.

Figure 2 and Figure 3 show ReCiPe indicators for scenarios 14 but for defected product handling phase only. We could observe that Scenario 2 is most impactful one, while Scenario 4 could even positively impact the environment. If we consider, that in Scenario 4 company does not undertake any repair or remanufacturing efforts and sends the defected part of a component batch to the supplier, we could agree that it does not include especially harmful processes. But it is the perspective of the company only and current production cycle. In the following cycle the missing components are delivered and the manufacturing process is to make up to the expected production volume. Actually, environmental pressures are moved to the supplier. The difference in assessment of scenarios 1 and 2 could be surprising, especially if Scenario 1 defect is more severe (product in manufacturing defect). But the seriousness of defect and its share in overall product weight and volume contribute also to the respectful environmental benefit obtained when the defected product is repaired and returned to manufacturing process.

We could see that the most affected is damage to resources category. It is very often the case while metal use is concerned and transport of heavy volumes for big distances. It is further confirmed by the highest score in metal depletion and second highest in fossil depletion impact categories. 


\subsection{Sensitivity analysis}

Final step of our research is sensitivity analysis on the basis of the number of defected products or component. We assume $1 \%$ increase of defective products / components share in the total batch. The results of the study are presented in Tab. V. We could observe that Scenario 3 is the most sensitive one for assumed change that in total causes $13,1 \%$ increase in environmental impact. This is due to the score of Scenario 3 that is balancing between positive and negative impact. Increase of the defected components share in Scenario 4 causes quite significant change in overall impact (worsening by $3,8 \%)$ and is similar to this achieved in Scenario $2(3 \%)$. Scenario 1 seems to the one that is not sensitive to the change and responds to it in $0,3 \%$ change of overall impact. In fact it is the only scenario for which change in overall score corresponds to the assumed change.

Table 5: $\quad$ SENSITIVITY ANAL YSIS OF SELECTED SCENARIOS WITH THE ASSUMPTION OF $1 \%$ INCREASE OF DEFECTS SHARE IN THE BATCH

\begin{tabular}{|c|r|r|r|r|}
\hline \multirow{2}{*}{$\begin{array}{c}\text { Alternative } \\
\text { scenarios }\end{array}$} & Total & $\begin{array}{c}\text { Human } \\
\text { Health }\end{array}$ & $\begin{array}{c}\text { Eco- } \\
\text { systems }\end{array}$ & Resources \\
\cline { 3 - 5 } & & 0,9442 & 0,3071 & 1,0389 \\
\hline alt S1 & 2,2902 & & & \\
\hline \% change to & & $-0,30 \%$ & $-0,30 \%$ & $1,10 \%$ \\
\hline S1 & $0,30 \%$ & 1,1924 & 0,3929 & 1,6927 \\
\hline alt S2 & 3,278 & $1,60 \%$ & $1,80 \%$ & $4,40 \%$ \\
\hline $\begin{array}{c}\text { change to } \\
\text { S2 }\end{array}$ & $3,00 \%$ & 0,1072 & 0,0433 & 0,0369 \\
\hline alt S3 & 0,1875 & & & \\
\hline $\begin{array}{c}\% \text { change to } \\
\text { S3 }\end{array}$ & $13,10 \%$ & $4,50 \%$ & $3,60 \%$ & $73,10 \%$ \\
\hline alt S4 & $-0,8425$ & $-0,2224$ & $-0,0782$ & $-0,5419$ \\
\hline $\begin{array}{c}\text { \% change to } \\
\text { S4 }\end{array}$ & $-3,80 \%$ & $-3,60 \%$ & $-3,50 \%$ & $-3,90 \%$ \\
\hline
\end{tabular}

\section{CONCLUSION}

The study shows some implications of company quality assurance system to its defective products handling outcomes with respect to environmental issues. Different scenarios that are defined on the basis of company defective product handling procedure and its practical implementation shows different level of impacts and different sensitivity. Surprisingly, these impacts are related mostly to the remanufacturing and repairing efforts that are undertaken by the company and are not significantly affected by transport of defected parts back to supplier. Life cycle assessments methods takes into account also environmental benefits from returning repaired products or its components to the manufacturing process. These results also show that the analysis is not completed yet and indicates some drawbacks of product system defined for the study. The next stage of the assessment should also cover efforts that are prescribed to the supplier and are also affecting the environment.

\section{REFERENCES}

[1] S. Agrawal, Singh, R.K., Murtaza, Q., Disposition decisions in reverse logistics: Graph theory and matrix approach, Journal of Cleaner Production 137 (2016) 93104

https://doi.org/10.1016/j.jclepro.2016.07.045

[2] A. Brzozowska, "Significance of production logistics in integrated IT systems", in Applied Mechanics and Materials, vol. 474, 2014, pp.423-427.

[3] P.Guarnieri, , Camara e Silva L., Levino N.A., Analysis of electronic waste reverse logistics decisions using Strategic Options Development Analysis methodology: A Brazilian case, Journal of Cleaner Production 133 (2016) 1105-1117 https://doi.org/10.1016/j.jclepro.2016.06.025

[4] K. Grondys, Theory of Spare Parts Inventory Management for Production Equipment, Advanced Logistic Systems. Theory and Practice, Vol.7, Nr. 1, 2013.

[5] A. Mesjasz-Lech, Economic effectiveness and environmental efficiency of reverse logistics (in Polish: Efektywność ekonomiczna i sprawność ekologiczna logistyki zwrotnej), Wyd. Politechniki Częstochowskiej, Częstochowa 2011.

[6] T. Nitkiewicz, M. Starostka-Patyk, Logistics of defective products in the context of life cycle assessment example of mobile phone (in Polish: Logistyka produktów niepełnowartościowych w ujęciu ekologicznej oceny cyklu życia - przykład telefonu komórkowego), Logistyka nr 3, s.4679-4686, 2014.

[7] A. Pabian, Koncepcja wieczystej restytucji jako proekologiczna alternatywa polityki zero zwrotów, "Organizacja i zarządzanie", no. 4, 2013, p. 120- 121.

[8] E. Pallaro, N. Subramanian, M.D. Abdulrahman, C. Liu, Sustainable production and consumption in the automotive sector: Integrated review framework and research directions, Sustainable production and consumption 4 (2015)47-61. https://doi.org/10.1016/j.spc.2015.07.002

[9] C. Prakash, M.K. Barua, A combined MCDM approach for evaluation and selection of third-party reverse logistics partner for Indian electronics, Sustainable Production and Consumption 7 (2016) 66-78. https://doi.org/10.1016/j.spc.2016.04.001

[10]M. Starostka-Patyk, Logistic management of defective products and motives of such products acceptance in the light of returns policy and company profitability. The case of Polish production companies, Proceedings of 2015 4th IEEE Int. Conf. on Advanced Logistics \& Transport (ICALT'2015). 20-22 May, 2015, Valenciennes, France, s.254-259, 2015. https://doi.org/10.1109/ICAdLT.2015.7136613

[11]P. Wieser, F.L. Perret and C. Jaffeux, Essentials of logistics \& management. The global supply chain. 3 edition, EPEL Press, Lausanne, 2012, pp.57-93. 